\title{
ACADEMIC PROCRASTINATION OF HIGH SCHOOL STUDENTS IN EAST JAVA
}

\author{
Arbin Janu Setiyowati*, Triyono, Indriyana Rachmawati \\ *Correspondent Author
}

\author{
Arbin Janu Setiyowati \\ Universitas Negeri Malang \\ Jalan Semarang Nomor 5, Sumbersari, \\ Lowokwaru, Malang, Jawa Timur, \\ Indonesia \\ Email:arbin.janu.fip@um.ac.id \\ Triyono \\ Universitas Negeri Malang \\ Jalan Semarang Nomor 5, Sumbersari, \\ Lowokwaru, Malang, Jawa Timur. \\ Indonesia \\ Email: triyono.fip@um.ac.id \\ Indriyana Rachmawati \\ Jalan Semarang Nomor 5, Sumbersari, \\ Lowokwaru, Malang, Jawa Timur \\ Indonesia \\ Email: indriyanabk@gmail.com \\ Page \\ 46-52
}

\begin{abstract}
Abstract This study aims to obtain a comprehensive view of academic procrastination committed by student in terms of cognitive, affective, and behavior. This study used a survey research method. The population of this research is high chool students in East Java and the research sample is 200 students spread over Malang, Blitar, Bangkalan, and Lamongan. The sampling technique used cluster random sampling and the data were analyzed using descriptive statistics. The result showed that the cognitive, affective, and psychomotor descriptions of students' academic procrastination were found. Counselors can use the findings of this study as the basis for developing BK services, especially in designing intervention strategies to reduce academic procrastination of high school students.

Kata kunci: academic procrastination, survey, descriptive
\end{abstract}

\section{PENDAHULUAN}

Academic procrastination is defined as a behavior of postponing school tasks. It emerges as one of the most controversial problems among students since it deals with time management skills and lack of autonomy (Ocak \& Boyraz, 2016; Shih, 2016; Saracaloglu et al., 2018; Borekci \& Uyangor, 2018). Procrastination emerges as a problem often faced by students due to their inability to manage their time and to be an autonomous learner.

From cognitive and behavioral perspectives, academic procrastination is divided into several types, namely procrastinating academic task, low procrastination, and procrastination perception (Solomon \& Rothblum, 1984). Procrastinating academic task consist of postponing reading paper (46\%), postponing preparation for exam
$(27.2 \%)$, and postponing weekly reading assignments $(30.1 \%)$. Low procrastination consist of procrastinating administration task $(10 \%)$, presence task $(23 \%)$ and participating in school events $(10.2 \%)$. Students who perceive themselves procrastinating reported that their problems are related to writing papers $(23.7 \%)$, preparation for exam $(21.2 \%)$ and weekly reading assignment $(23.7 \%)$. These three description of procrastination was found among students in 1984 by Solomon and Rothblum where the greatest problem of academic procrastination is related to writing paper, preparing for exam, and weekly reading assignment.

Another study found that most of high school students aged of 15 years old experience academic procrastination (Ozer, 2011). It was also found that university students procrastinate due to social media 


\title{
47|PSIKOPEDAGOGIA
}

\author{
JURNAL BIMBINGAN DAN KONSELING
}

Vol.9, No.1, June 2020

usage (Muslikah, M., \& Andriyani, A, 2018). These studies show that procrastination still emerges as a crucial problem among students. A study conducted in senior high schools in East Java in 2019 showed that $50 \%$ of the students procrastinates in term of cognitive (their perception of procrastination), affective (their feeling when procrastinate), and psychomotor (problems leading to procrastination). The result of the study confirm that students still procrastinate in doing their school task.

Academic procrastination adversely affect students' academic achivement at school. It is proven that students who academically procrastinate tend to exhibit lower academic achivement (Borekci \& Uyangor, 2018; Korkmaz et al., 2018; Asri et al., 2017). Finding of these studies provide enough description of adverse effect of academic procrastination. Furthermore, another study found that procrastination does not only deal with learning skill or time management deficit but also involves complex interaction between behavioral, cognitive, and affective aspects of individuals (Saracaloglu et al., 2018). Accordingly, it is necessary to depict senior high school students' academic procrastination from both teachers' and students' perspective. The purpose of the present study was to obtain a holistic depiction of students' academic procrastination from cognitive, affective, and behavioral perspectives.

\section{METHODOLOGY}

The present survey study involved senior high school students in four East Java regencies, namely Malang, Blitar, Bangkalan, and Lamongan The sample of the study wwas 200 students and 20 school teachers in four regencies previously mentioned. They were recruited using cluster random sampling technique. The data were collected by distributing academic procrastination scale, the scale was developed by the researchers themselves based on procrastination theory. The data were analyzed descriptively to describe students' academic procrastination.

\section{RESULT AND DISCUSSION}

The study was conducted in senior high schools in four cities in East Java, namely Malang, Blitar, Bangkalan, and Lamongan. Students participated in this study were tenth and eleventh-grade students from language, natural science, and social departments. Teachers were also recruited as participants of the study in order to gain in-depth understanding related to the result of the study. Teacher-participants in the present study were school principals, teachers, and school counselor.

It was found that exact subjects (e.g., math) stands highest percentage of late submission, compared to other subjects, Regarding students' behavior related to homework, most of the students prefer to do it gradually until the deadline. Regarding the students' behavior when given classroo tasks, most of the students stated that they prefer to discuss the tasks with their deskmate. This study found that the greatest hindrance in task submission, according to the students, was task overload. Thus, the students' effort to overcome such hindrance is to make a priority list of the assignment. The following table 1 displays the collected data.

Table 1

Description of Students' Academic Procrastination

\begin{tabular}{|c|c|c|}
\hline No & Description & Percentage \\
\hline \multirow[t]{4}{*}{1} & $\begin{array}{l}\text { Students' view of ontime school } \\
\text { task submission }\end{array}$ & \\
\hline & $\begin{array}{l}\text { Submitting tasks on the agreed } \\
\text { hour. }\end{array}$ & $73 \%$ \\
\hline & $\begin{array}{l}\text { As long as the tasks are } \\
\text { submitted in the same day }\end{array}$ & $45 \%$ \\
\hline & $\begin{array}{l}\text { It is no problem to submit late, as } \\
\text { long as the teacher allows. }\end{array}$ & $27 \%$ \\
\hline \multirow[t]{4}{*}{2} & $\begin{array}{l}\text { Subjects with highest rate of late } \\
\text { submission. }\end{array}$ & \\
\hline & Mathematic & $44 \%$ \\
\hline & Physics & $31 \%$ \\
\hline & Others & $28 \%$ \\
\hline \multirow[t]{5}{*}{3} & $\begin{array}{l}\text { Students' behavior when given a } \\
\text { homework }\end{array}$ & \\
\hline & $\begin{array}{l}\text { Doing homework gradually until } \\
\text { the given deadline. }\end{array}$ & $47 \%$ \\
\hline & $\begin{array}{l}\text { Doing groupwork to finish } \\
\text { assignment }\end{array}$ & $31 \%$ \\
\hline & $\begin{array}{l}\text { Doing the homework near the } \\
\text { deadline }\end{array}$ & $31 \%$ \\
\hline & $\begin{array}{l}\text { Studying by watching tutorial in } \\
\text { websites to finish assignment }\end{array}$ & $29 \%$ \\
\hline 4 & $\begin{array}{l}\text { Students' behavior when given } \\
\text { classroom assignment }\end{array}$ & \\
\hline
\end{tabular}




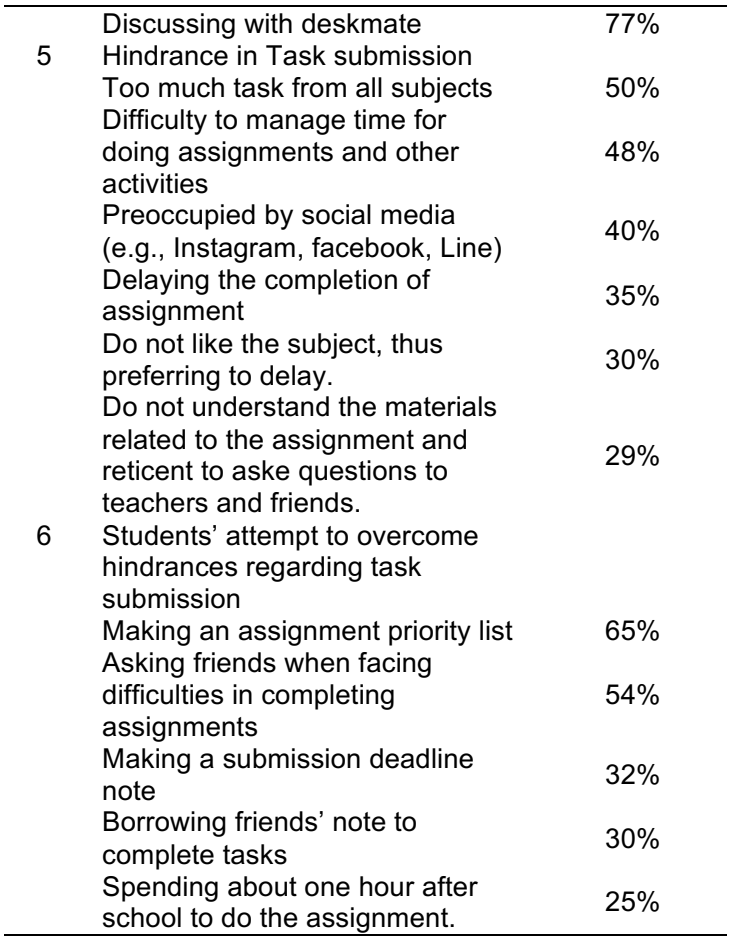

The survey on teachers related to the students' academic procrastination showed that the teachers' perception of students' late submission was that the students were lazy and used to delay the task. In addition, they perceive procrastinating students are those with low academic achievement. Some teachers state that most of the students submit their work ontime, although some of them are late. Other conditions that lead to students' late submission are unexpected hindrances and students' personal, academic, and social problems. Teachers view that most of the students also submit their works late in another subject that is not tested in national exam, namely Japanese Language subject. For subjects tested in national exam, majority of students submit their works late in physics and chemistry. According to teachers, to overcome their late submission problem, students should have a consultation, asking for deadline, and immediately do the given tasks. Other efforts the student made to submit their works on time is by doing the given assignment while performing other activities.

The problems mostly faced by the students are task overload, i.e., the students are given too many task at the same day in every subject. Teachers viewed that students' procrastination occur due to their bad habit, poor time management, friend's persuasion, lack of understanding of the materials, and task difficulty. To reduce the students' problem of late submission, teachers attempted to give reward, set the deadline, impose punishment, give no deadline extension, and monitor the progress. The collected data are displayed in in table 2.

Table 2

Students Academic Procrastination from Teachers' Perspective

\begin{tabular}{|c|c|c|}
\hline No & Description & Percentage \\
\hline \multirow[t]{6}{*}{1} & $\begin{array}{l}\text { Teachers' perception of students' } \\
\text { late submission }\end{array}$ & \\
\hline & $\begin{array}{l}\text { Students who submit their work } \\
\text { late are lazy and use to delay } \\
\text { doing their work. }\end{array}$ & $100 \%$ \\
\hline & $\begin{array}{l}\text { Students who submit their work } \\
\text { late usually have lower academic } \\
\text { achievement }\end{array}$ & $100 \%$ \\
\hline & $\begin{array}{l}\text { Most of the students submit their } \\
\text { work ontime }\end{array}$ & $55 \%$ \\
\hline & $\begin{array}{l}\text { Some of students submit their } \\
\text { works late }\end{array}$ & $50 \%$ \\
\hline & Others & $35 \%$ \\
\hline \multirow[t]{4}{*}{2} & $\begin{array}{l}\text { Teachers' observation on } \\
\text { students' tendency of late } \\
\text { submission }\end{array}$ & \\
\hline & Others & $55 \%$ \\
\hline & Physics & $35 \%$ \\
\hline & Chemistry & $30 \%$ \\
\hline \multirow[t]{7}{*}{3} & $\begin{array}{l}\text { Teachers' observation on } \\
\text { students' effort to finish the given } \\
\text { assignment }\end{array}$ & \\
\hline & $\begin{array}{l}\text { Students consult the teacher } \\
\text { when facing difficulties }\end{array}$ & $70 \%$ \\
\hline & Students ask for deadline & $60 \%$ \\
\hline & $\begin{array}{l}\text { Students immediately do the } \\
\text { given assignment }\end{array}$ & $45 \%$ \\
\hline & $\begin{array}{l}\text { Students do other activities while } \\
\text { working on the given assignment }\end{array}$ & $35 \%$ \\
\hline & $\begin{array}{l}\text { Students submit their work } \\
\text { ontime }\end{array}$ & $30 \%$ \\
\hline & $\begin{array}{l}\text { Students tend to submit the task } \\
\text { late }\end{array}$ & $30 \%$ \\
\hline \multirow[t]{7}{*}{4} & $\begin{array}{l}\text { Problems related to students' } \\
\text { punctual submission. }\end{array}$ & \\
\hline & $\begin{array}{l}\text { Every subjects leave a homework } \\
\text { for students }\end{array}$ & $100 \%$ \\
\hline & Students' procrastination & $65 \%$ \\
\hline & $\begin{array}{l}\text { Students' lack of time } \\
\text { management }\end{array}$ & $50 \%$ \\
\hline & $\begin{array}{l}\text { Friends persuade others to } \\
\text { postpone doing the task }\end{array}$ & $45 \%$ \\
\hline & Students' lack of mastery & $40 \%$ \\
\hline & Task difficulty & $25 \%$ \\
\hline 5 & $\begin{array}{l}\text { Teachers' effort to reduce } \\
\text { students' late submission }\end{array}$ & \\
\hline
\end{tabular}




\begin{tabular}{lc}
\hline $\begin{array}{l}\text { problem } \\
\text { Giving rewards for those } \\
\text { submitting ontime }\end{array}$ & $80 \%$ \\
$\begin{array}{l}\text { Setting a clear, rational deadline } \\
\text { Imposing punishment to students }\end{array}$ & $60 \%$ \\
$\begin{array}{l}\text { who submit their work late } \\
\text { Do not provide deadline } \\
\text { extension }\end{array}$ & $50 \%$ \\
$\begin{array}{l}\text { Monitoring the task completion } \\
\text { progress }\end{array}$ & $50 \%$ \\
\hline
\end{tabular}

Based on the result of the study, it could be concluded that students' academic procrastination can be categorized in the form of cognitive, attitude and value, and skill. These categories cover the following.

1. 1) In terms of cognitive aspect, students procrastination include (a) submitting tasks on the agreed hour, (2) submitting task in the agreed day, (3) submitting task as long as the teachers allow, despite the lateness. In terms of attitude and value, students' academic procrastination was caused by (a) work overload (i.e., every subject leaves a homework), (b) difficulty to manage time for assignment and other activities, (c) social media preoccupation, (d) habit of postponing task, (e) lack of interest in the subject, and (f) lack of understanding of material and reticent to ask questions. In terms of skill, it is shown by (a) doing the task gradually, (2) forming a study group, (c) doing the homework near the deadline, (d) discussing the task with deskmate, (e) making priority list, (f) asking friends when facing difficulty, (g) making deadline note, (h) borrowing friend's note, and (i) doing the task after school hour.

2. From the teachers' perspective, students who proctastinate (a) are lazy and use to postpone the task and (b) have low academic achievement, Teachers viewed that (c) most of students submit their works ontime. (d) However, some of them submit their works late. It was also found that students' procrastination was caused by their personal, academic, or social problems. In terms of attitude and value, students procrastinate due to (a) work overload, (b) students' habit, (c) poort time management, (d) friends' persuasion to postpone the given task, (e) lack of understanding, and (f) difficulty when doing the work. In terms of skill, according to the teachers, the students need to (a) consult their work, (b) ask about the deadline, (c) and do the task immediately. They should not (d) do the task while doing other activities. Teachers views that students should (e) submit their works ontime. The students (f) tend to submit their work late. Accordingly, as teachers' attempt in reducing students procrastination, (g) teachers gave rewards for students who submit their work ontime, (h) set the deadline, (i) imposing punishment to students who submit their work late, (j) did not provide deadline extension, and (j) monitor the task completion progress.

The present study showed that senior high school students procrastinated to do the school assignment. According to the teachers, most of them submit the task late. They who procrastinated are usually students with low academic achievement. This is consistent with Borekci \& Uyangor (2018); Korkmaz et al., (2018); Asri et al., (2017) who stated that students who procrastinate, in general, are those with lower academic achievement. Saracaloglu et al., (2018) adds that students who procrastinates are careless, lazy, passive, and stagnant. Such students are not responsible for their academic activities.

Academic achievement is negatively correlated with procrastination (Akpur, 2017; Kurtovic et al., 2019). In other words,students with higher academic achievement exhibit lower procrastination behavior, and vice versa. Most of the senior high school students in East Java $(44 \%)$ procrastinate in mathematic subjects. This finding supports Akinsola et al (2007) who states that academic procrastination is related to the students' time management, efforts ouside the classroom to learn the given materials. (2007). Students' high procrastination in math subject was caused by their lack of effort to improve their understanding outside the classroom.

Students' procrastination in math subject may be accounted for by their lack of knowledge or skill, low motivation, low commitment to do the homework, and 
excessive use of social media (Fulano et al., 2018). In Fulano et al.'s (2018) study, lack of skill emerges as the main reason of academic procrastination. Students'high academic procrastination may be accounted for by their lack of knowledge or skill since they only receives the materials given by the teachers at school without attending additional courses outside the school time. In addition, high social media usage is also seen as another reason of students' academic procrastination. Students' social environment may faciliate them to reduce their academic procrastination (Nordby et al., 2017). In other words, students' social environment (including peer), influence students' academic procrastination habit.

Most of the students in this study failed to submit their work ontime because they were preoccupied by social media, this factor influence their procrastination by $40 \%$, beside other factors. This is consistent with Efe and Efe (2018) who found that social media use affects students' academic procrastination. Other factors leading to academic procrastination are task overload, poor time management, procrastinating habit, lack of interest, and lack of understanding. Task overload, lack of interst and understanding makes students reticent to do the given tasks, Such powerless perception makes students procrastinates (Prihadi et al., 2018). Such perception emerges because the given task is beyond the students' ability, for instance, when they are given too many task at the same day and they lacked understanding of the materials. The teachers in this study agreed that the the students' problem related to work submission are task overload, students' procrastination habit, poor time management, friends' negative influence, lack of understanding, and difficulty level of the given task.

In order to prevent themselves from procrastinating, they do the homework gradually, make a study group, do the homework near the deadline, watching tutorial on the internet, discuss with firends, make a priority list, make a small notes, and spend one hour after school to finish the given assignment. According to the teachers, students try to overcome such problems by consulting their teachers, asking for deadline, immediately do the given tasks, or doing the assignment while performing other activities. These efforts were made to submit the given task ontime. Efforts and academic hardiness motivates students to finish their task ontime (Wu and Fan, 2016).

Meanshiwle, teachers' effort to reduce the students' procrastination was in the form of reward, setting the deadline, sanction, giving no deadline extension, and monitoring the task completion progress. Students' time management skill is not enough to reduce procrastination, it is necessary to have teachers' support to monitor the students' progress (Ocak \& Boyraz, 2016). In other words, teachers' attention to their teachers (e.g., monitoring the progress, giving rewards or punishments, and setting deadline) is important to minimize students' academic procrastination. In addition, it is important to deliver the materials properly so that the students can understand the materials.

Another strategy to minimize academic procrastination, according to Zhang et al (2018), is by driving students to push their fear of failure, thus enhancing their self-esteem. Students who manage to overcome their fear of failure show that they have a confidence in managing themselves in academic activities and possess better self-esteem that may minimize procrastination behavior. High selfconfidence may prevent students from procrastinating (Grunschel \& Schopenhauer, 2015; Lowinger et al., 2016; Malkoc \& Mutlu, 2018). Accordingly, teachers need to take a role in minimizing the students' procrastination by improving their self-confidence. Moreover, parents also play important role in minimizing students' procrastination.

Family members should show their support to the students to prevent them from procrastinating (Borekci \& Uyangor, 2018). The description above shows that academic procrastination is not only teachers' responsibility but also parents' responsibility to prevent it. Parents are expected to help students manage their time effectively, parents critique on their children's failure may lead to fear of failure, which potentially lead to academic procrastination (Shih, 2016). This 


\section{1 |PSIKOPEDAGOGIA}

JURNAL BIMBINGAN DAN KONSELING

Vol.9, No.1, June 2020

study showed that students need their parents' reasonable expectation, instead of their critique, in order to minimize academic procrastination.

\section{CONCLUSION}

Students' academic procrastination can be viewed from the interaction among one's cognitive, affective, and skill. It was reported that the students' procrastination was caused by task overload, procrastination habit, and lack of understanding of the materials given. However, they attempt to overcome their procrastination by working on the given tasks gradually, making a study group, making a priority list, asking their friends, making a deadline note, borrowing friends' note, and spending afterschool time to do the homework.

\section{REFERENCES}

Akinsola, M.K., Tella, A., dan Adeyinka T. (2007). Correlates of Academic Procrastination and mathematics achievement of university undergraduate students. Eurasia Journal of Mathematics, Science, \& Technology Education, 3(4): 363-370.

Akpur, U. (2017). Predictive and explanatory relationship model between procrastination, motivation, anxiety and academic achievement. Eurasian Journal of Educational Research, 69: 221-240.

Asri, D.N., Setyosari, P., Imanuel H., dan Tutut C. (2017). The academic procrastination in junior high school students' mathematics learning: A Qualitative Study. International Education Studies, 10(9): 70-77.

Borekci, C., dan Uyangor Borekci, C., dan Uyangor, N. (2018). Family attitude, academic procrastination and test anxiety as predictors of academic achievement. International Journal of Educational Methodology, 4(4): 219226.

Efe, H.A dan Efe, R. (2018). The relationship between academic procrastination behaviors of preservice science teachers and their attitudes toward social media. Journal of Education and e-Learning Research, 5(2): 102-109.

Fulano, C., Cunha, J., Jose C.N., Beatriz P., dan Pedro R. (2018). Mozambican adolescents' perspective on the academic procrastination process. School Psychology International, 39(2), 196-213.

Grunschel, C., \& Schopenhauer, L. (2015). Why are students (not) motivated to change academic procrastination?: An investigation based on the transtheoretical model of change. Journal of College Student Development, 56(2), 187-200.

Korkmaz, O., Ilham, T., dan Salih B. (2018). An investigation of self-efficacy, locus of control, and academic procrastination as predictors of academic achievement in students diagnosed as gifted and nongifted. European Journal of Education Studies, 4(7): 173-192.

Kurtovic, A., Vrdoljak, G., dan Anita I. (2019). Predicting procrastination: the role of academic achievement, self-efficacy and perfectionism. International Journal of Educational Psychology, 8(1), 1-26.

Lowinger, R. J., Kuo, B. C. H., Song, H.-A., Mahadevan, L., Kim, E., Liao, K. Y.-H., ... Han, S. (2016). Predictors of academic procrastination in asian international college students. Journal of Student Affairs Research and Practice, 53(1), 90-104.

Malkoc, A dan Mutlu, A.K. (2018). Academic self-efficacy and academic procrastination: exporing the mediating role of academic motivation in turkish university students. Universal Journal of Educational Research, 6(10): 20872093.

Muslikah, M., \& Andriyani, A. (2018). Social media user students' academic procrastination. Psikopedagogia Jurnal Bimbingan dan Konseling. 7(2). 53-57

Nordby, K., Klingsieck, K. B., \& Svartdal, F. (2017). Do procrastination-friendly environments make students delay unnecessarily? Social Psychology of Education, 20(3), 491-512. 
Ocak, G., dan Boyraz, S. (2016). Examination of The relation between academic procrastination and time management skills of undergraduate in terms of some variables. Journal of Education and Training Studies, 4(5): 76-84.

Ozer, B.U. (2011). Cross sectional study on procrastination: Who procrastinate more?. International Conference on Education, Research and Innovation, 18: 34-37.

Prihadi, K., Tan, C.Y.H., Reimy T.S. Tan, P.L Yong, Jonathan H. E., Yong S.T., Chee Leong Goh, dan Yu Jin Tee. (2018). Mediation role of locus of control on the relationship of learned-helplessness and academic procrastination. International Journal of Evaluation and Research in Education, 7(2): 87-93.

Saracaloglu, A.S., Dincer, B., dan Ceren S.G. (2018). The relationship between music teacher candidates' academic and general procrastination tendencies and test anxiety. Journal of Education and Training Studies, 6(9): 174-183.

Shih, S.-S. (2016). Factors related to Taiwanese adolescents' academic procrastination, time management, and perfectionism. The Journal of Educational Research, 110(4), 415-424.

Solomon, L.J dan Rothblum, E.D. (1984). Academic procrastination: frequency and cognitive-behavior correlates. Journal od Counseling Psychology, 31(4): 503-509.

Wu, F., \& Fan, W. (2016). Academic procrastination in linking motivation and achievement-related behaviours: a perspective of expectancy-value theory. Educational Psychology, 37(6), 695711.

Zhang, Y., Dong, S., Wenjie Fang, Xiaohui Chai, Jiaojiao Mei, dan Xiuzhen Fan. (2018). Self-efficacy for self-regulation and fear of failure as mediators between self-esteem and academic procrastination among undergraduates in health professions. Advances in Health Sciences Education, 23(4), 817830. 